\title{
Revision of food-based dietary guidelines for Ireland, Phase 2: recommendations for healthy eating and affordability
}

\author{
Mary AT Flynn*, Clare M O’Brien, Victoria Ross, Cliona A Flynn and Sarah J Burke \\ Department of Public Health Nutrition, Food Safety Authority of Ireland (FSAI), Abbey Court, \\ Lower Abbey Street, Dublin 1, Republic of Ireland
}

Submitted 30 November 2010: Accepted 8 July 2011: First published online 14 September 2011

\begin{abstract}
Objective: To revise the food-based dietary guidelines for Ireland and assess the affordability of healthy eating.

Design: An iterative process was used to develop $4 \mathrm{~d}$ food intake patterns ( $n$ 22) until average intakes met a range of nutrient and energy goals (at moderate and sedentary activity levels) that represented the variable nutritional requirements of all in the population aged 5 years and older. Dietary guidelines were formulated describing the amounts and types of foods that made up these intake patterns. Foods required for healthy eating by typical households in Ireland were priced and affordability assessed as a proportion of relevant weekly social welfare allowances. Setting: Government agency/community.

Subjects: General population aged $5+$ years.

Results: Food patterns developed achieved energy and nutrient goals with the exception of dietary fibre (inadequate for adults with energy requirements $<9 \cdot 2 \mathrm{MJ}$ ) and vitamin D (inadequate for everyone). A new food group to guide on fats/oils intake was developed. Servings within the Bread, Cereal and Potato group were sub-categorized on the basis of energy content. Recommendations on numbers of servings from each food group were developed to guide on energy and nutrient requirements. Healthy eating is least affordable for families with children who are dependent on social welfare.

Conclusion: Daily supplementation with vitamin D is recommended. Wholemeal breads and cereals are recommended as the best source of energy and fibre. Lowfat dairy products and reduced-fat unsaturated spreads are prioritized to achieve saturated fat and energy goals. Interventions are required to ensure that healthy eating is affordable.
\end{abstract}

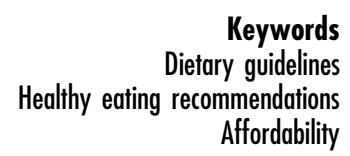

It is important to periodically review dietary guidelines to ensure that the dietary prevention of diseases most pertinent for a given population underpin healthy eating advice $^{(1,2)}$. Rising obesity rates now affect all age groups in Ireland ${ }^{(3-6)}$ and diet-related chronic diseases such as CVD, cancer and osteoporosis ${ }^{(7-9)}$ still remain important public health concerns. Over the past 3 years Ireland has experienced a major economic downturn where unemployment has risen from an average of $4.6 \%$ in 2007 to $13 \cdot 7 \%$, according to the latest figures for $2010^{(10)}$. Low income is associated with poor nutrition at all life stages, which in turn has major consequences for health ${ }^{(11)}$, such as a higher risk of diet-related chronic diseases ${ }^{(12)}$. There is also well-established evidence that the prevalence of obesity is higher among those from socio-economically disadvantaged groups ${ }^{(13,14)}$.

To provide optimal nutrition in the context of obesity prevention, Ireland's national food guide (1993-2010) was recently evaluated in order to identify and prioritize the areas most in need of revision ${ }^{(15)}$. This evaluation found that food patterns based on the current food guide provided excessive energy, total and saturated fat but inadequate fibre and vitamin $\mathrm{D}$ intakes ${ }^{(15)}$. In addition, some impracticalities were also identified in the food choice advice, most notably in the wide range of energy provided by foods in the Bread, Cereal and Potato group and the need to convey meaningful portion sizes to consumers.

There are several methods that may be used in the development of food-based dietary guidelines. However, information on population-based approaches which include guidance on energy intakes is very limited and available only for the USA ${ }^{(16)}$. In the USA, the extensive technical process used to develop the most recent guidelines focused mainly on the development of food intake patterns that met established nutrient goals without providing excessive energy ${ }^{(17)}$. This involved the iterative 
development of daily food patterns for all age and gender subgroups of the population ${ }^{(16)}$. General healthy eating guidelines, e.g. 'use low-fat dairy products', were then derived from the amounts and types of foods used in the food patterns.

The effectiveness of food-based dietary guidelines depends on many factors, including development of appropriate advice on foods commonly consumed and communication which includes wording and a graphic model such as a pyramid, a rainbow or a plate. Another major issue relating to the uptake of dietary advice is affordability. Assessment of the cost of healthy eating is critical to ensure that healthy eating is accessible for all. The latest figures available show that in 2009, the number of people living in Ireland in consistent poverty (having an income below $60 \%$ of the median income in Ireland and experiencing enforced deprivation) was 5.5\% and the number of people at risk of poverty (having an income below $60 \%$ of the median income in Ireland) was $14 \cdot 1 \%^{(18)}$. Unemployment in Ireland has more than doubled since $2008^{(10)}$, and disposable household income (per household) has also fallen by $6 \cdot 3 \%$ between 2008 and $2009^{(18)}$. This is a significant consideration as energy-dense foods which are higher in fat and sugar tend to be cheaper than foods recommended for healthy eating such as fruit and vegetables ${ }^{(13,14)}$. Surveys in Ireland have indicated that access to affordable, good-quality, nutritious foods is a major challenge to low-income families and that social disadvantage is associated with higher fat intakes ${ }^{(19,20)}$.

Following the evaluation of Ireland's food guide $(1993-2010)^{(15)}$, the present paper describes the approaches used for revision of dietary guidelines in Ireland and the recommendations for healthy eating advice that were formulated as a result. In addition, the paper includes an examination of the affordability of these new recommendations.

\section{Methods}

Goals for energy, macronutrients ${ }^{(21)}$, fibre ${ }^{(22,23)}, \mathrm{Fe}^{(24)}, \mathrm{Ca}$ and vitamin $\mathrm{D}^{(25)}$ were set for males and females over 5 years of age as described in Phase I of this revision ${ }^{(15)}$. In addition, the UK goal of $\leq 10 \%$ of energy from nonmilk extrinsic sugars ${ }^{(26)}$ was also used. Four-day food intake patterns were developed for twenty-two hypothetical males and females that were drawn from the four chosen age categories that represented the Irish population from age 5 years to $51+$ years. The daily energy goals from these food intake patterns ranged from 5.9 to $11 \cdot 7 \mathrm{MJ}(1400-2800 \mathrm{kcal})$ providing different patterns that represented every $837 \mathrm{~kJ}$ (200 kcal) increase. The food patterns were developed to reflect the typical eating habits of various age and gender groups in Ireland. First, nutritionists experienced in assessing dietary intakes in Ireland constructed the initial food intake patterns using foods commonly eaten, as identified in recent national nutrition surveys undertaken on adults ${ }^{(27)}$, teenagers ${ }^{(28)}$ and children ${ }^{(29)}$. Second, the additional input of dietitians currently working in public health, paediatrics and geriatrics was obtained to ensure the food patterns generated for the different age and gender groups reflected typical eating habits. These patterns were then repeatedly adjusted involving the use of different types and quantities of foods (e.g. low-fat dairy, lean meats, unsaturated spreads and oils, and occasional use of sugar, preserves on wholemeal foods or 'other foods'), which were analysed and re-analysed for energy and nutrient output using the software Netwisp version $3 \cdot 0$ (Tinuviel Software, Anglesey, UK). Repeated adjustments were made until the food patterns approached the energy and nutrient goals. The percentage of energy contributed by non-milk extrinsic sugars for each of the food patterns was estimated, based on the method used in the UK National Food Surveys ${ }^{(30)}$. These sugars included the sum of: total sugars derived from table sugar and unsweetened fruit juices; half of the fruit sugar plus added sugar in preserves, stewed fruit and canned fruit; total sugars in breakfast cereals; non-milk sugars in yoghurts, milk puddings and ice cream; and total sugars found in composite dishes such as apple pie.

When nutrient outputs approached the goals, the amounts and types of foods used in the patterns were used as a basis for the recommended numbers of servings from each of the food groups to cover the energy and nutrient requirements according to age and gender. Further detailed advice on food choice was developed as appropriate to cover other aspects of healthy eating, e.g. use of unsaturated fats and oils to achieve low saturated fat intakes.

According to stakeholder preferences (see Phase I of this revision ${ }^{(15)}$ ), the portion sizes of the foods in the Bread, Cereal and Potato group were enlarged and some were described using a $200 \mathrm{ml}$ disposable cup where appropriate. These portions were sub-divided according to energy content into four categories ranging from $418 \mathrm{~kJ}$ to $920 \mathrm{~kJ}(100-220 \mathrm{kcal})$ in $126 \mathrm{~kJ}(30 \mathrm{kcal})$ increments.

To assess the affordability of foods needed for healthy eating, the four most common household types in Ireland were identified as described by Ross et al. ${ }^{(31)}$. Three major retail outlets were surveyed throughout November 2008. These included a nationwide multiple grocery store chain, a low-cost nationwide grocery store and a local store. The amounts of foods used in each food pattern were costed according to the weight used. Where more than one brand of food product was available, the cheapest price was recorded. In addition, the specific cost of fruit and vegetables, fat spreads and oils and 'other foods' such as snacks, sugar and preserves per $418 \mathrm{~kJ}$ (100 kcal) provided was calculated. Affordability was initially assessed according to social welfare allowances available in 2008. For the present study, affordability was 
updated taking account of the 2010 National Budget and the $6.4 \%$ fall in food prices since $2010^{(32,33)}$.

\section{Results}

Table 1 shows the daily amounts of energy, macronutrients, fibre, $\mathrm{Ca}, \mathrm{Fe}$ and vitamin D provided by the twenty-two food intake patterns. The food patterns provide daily energy ranging from 5.9 to $11.7 \mathrm{MJ}(1400-2800 \mathrm{kcal})$, with several representations of each $837 \mathrm{~kJ}$ ( $200 \mathrm{kcal})$ increment. For those aged $\geq 14$ years, energy requirements for sedentary levels of activity are also included. Nineteen of the food patterns were within $41.8 \mathrm{~kJ}$ (10 kcal) and three were within $70 \mathrm{~kJ}(16 \mathrm{kcal})$ of the energy goals. All of the food patterns met the goals for total fat, carbohydrate and protein. The saturated fat intakes ranged from $8 \%$ to $11 \cdot 2 \%$ of energy and non-milk extrinsic sugar intakes ranged from $6 \%$ to $11.5 \%$ of energy. Adjustment of food patterns attempting to reach the higher energy goals for males aged 14-50 years led to marginally excessive saturated fat intakes $(11 \cdot 2 \%$ of energy for males aged 14-18 years and $10 \cdot 7 \%$ of energy for males aged $19-50$ years both requiring $11.7 \mathrm{MJ}(2800 \mathrm{kcal}))$.

All food intake patterns for those up to 18 years reached the goal of 'age $+5 \mathrm{~g}$ fibre' per day. The $25 \mathrm{~g} / \mathrm{d}$ goal for fibre was reached in adult food intake patterns providing $10 \mathrm{MJ}(2400 \mathrm{kcal})$ or more. The food intake patterns for females aged $51+$ years had more added sugar $(10.9 \%$ and $11.5 \%)$ compared with the goal of $\leq 10 \%$ of energy from non-milk extrinsic sugars, yet due to relatively low energy requirements, fibre intake reached only $16-17 \mathrm{~g} / \mathrm{d}$ (64-68\% of the fibre goal).

The goals (Estimated Average Requirements) for Fe intake were reached. Ca intakes for 9-10-year-old children with daily energy requirements $<9 \cdot 2 \mathrm{MJ}$ (2200 kcal) reached approximately $78 \%$ of the goal of $1300 \mathrm{mg} / \mathrm{d}$. The food intake patterns for males and females aged $51+$ years achieved between $94 \%$ and $111 \%$ of the goal of $1200 \mathrm{mg} \mathrm{Ca} / \mathrm{d}$. Despite best attempts to incorporate foods containing vitamin $\mathrm{D}$ into the food patterns, intakes remained inadequate for almost all of the food patterns.

The recommended numbers of daily servings from the main food groups are outlined in Table 2. Servings from the Bread, Cereal and Potato group vary according to energy requirements. For males aged 19-50 years, servings from the dairy (Milk, Yoghurt and Cheese) group vary, and for males aged 14-50 years servings from the Meat, Fish and Alternatives group vary in order to meet higher energy requirements. Fat Spreads and Oils are separated from all Other Foods such as biscuits, cakes, chocolate and confectionery, enabling clearer advice on types and amounts of these foods to be provided. Separate advice is also provided on the use of sugars and preserves to increase palatability of low-fat, high-fibre cereals, breads and fruit as distinct from other uses.
The final portion sizes of foods in the Bread, Cereal and Potato group (see Table 3) were derived to reflect nutritionists/dietitians' and consumers' preferences for larger portions deemed to be more meaningful ${ }^{(15)}$. The use of a $200 \mathrm{ml}$ cup to indicate portion size was also incorporated ${ }^{(15)}$.

Table 4 describes the main recommendations for healthy eating derived from both the evaluation of Ireland's food guide ${ }^{(15)}$ and the development of the twenty-two food intake patterns for different age and gender groups. Other recommendations, outside the development of food-based dietary guidelines, include supplementation with folic acid, breast-feeding and food safety.

The cost $(€)$ and percentage (\%) of weekly social welfare allowance and child benefit required to purchase the foods contained in the food intake patterns for the four most typical households using three different grocery store outlets are shown in Table 5 . The results show that families with children, particularly older children, incur the greatest cost $(€ 132 \cdot 40)$ representing approximately $30 \%$ of social welfare allowance, while the lowest costs are incurred by females aged $65+$ years who live alone (costing $€ 32 \cdot 40$, representing approximately $15 \%$ of their social welfare allowance). The cost of shopping in 'local shops' compared with a multiple supermarket is on average twice as expensive. Calculating the specific cost of healthy eating for children using their social welfare allowances (i.e. the child dependency allowance plus the child benefit), it was found that covering the cost for the older child took up his entire social welfare income. The cost of fruit and vegetables per $418 \mathrm{~kJ}$ ( $100 \mathrm{kcal}$ ) was found to be $€ 0 \cdot 45$; the cost of 'other foods' such as snacks, sugar, preserves, etc. per $418 \mathrm{~kJ}(100 \mathrm{kcal})$ was $€ 0 \cdot 17$ and that of fat spreads and oils was only $€ 0 \cdot 04 / 418 \mathrm{~kJ}(100 \mathrm{kcal})$.

\section{Discussion}

The present paper describes the revision of Ireland's dietary guidelines, developed for the population of Ireland over 5 years of age, based on food patterns that achieved well-established nutrient goals within energy requirements at sedentary and moderately active physical activity levels. Guidance on the type and amount of food required for healthy eating was developed from these patterns in terms of numbers of servings from each of the food groups. The portions of foods in the Bread, Cereals and Potato group were sub-categorized according to energy content to give improved guidance on energy. In relation to vitamin $\mathrm{D}$, it was concluded that the best strategy to ensure adequacy for all age and gender groups was to recommend supplementation. To achieve goals for total fat and saturated fat, guidance indicated preferential use of low-fat dairy foods, lean meats as well as unsaturated fats and oils. Furthermore, separation of fats and oils in to a new food group facilitated clearer direction on the type and amounts of these foods required. Finally, advice 
Table 1 Daily energy and nutrients provided by twenty-two $4 \mathrm{~d}$ food intake patterns finalized for the development of food-based dietary guidelines on healthy eating, for moderately active males and females representative of Ireland's population aged 5 years and older

\begin{tabular}{|c|c|c|c|c|c|c|c|c|c|c|c|c|c|c|c|}
\hline \multirow[b]{3}{*}{ Sub-population } & \multicolumn{15}{|c|}{ Energy and nutrient intakes } \\
\hline & \multicolumn{2}{|c|}{ Energy* $^{*}$} & \multicolumn{2}{|c|}{ Total fat } & \multicolumn{2}{|c|}{ Saturated fat } & \multicolumn{2}{|c|}{ Protein } & \multicolumn{2}{|c|}{ Carbohydrate } & \multirow{2}{*}{$\frac{\text { NMES }}{\% E}$} & \multirow{2}{*}{$\frac{\text { Fibre }}{g}$} & \multirow{2}{*}{$\frac{\mathrm{Fe}}{\mathrm{mg}}$} & \multirow{2}{*}{$\frac{\mathrm{Ca}}{\mathrm{mg}}$} & \multirow{2}{*}{$\frac{\text { Vitamin D }}{\mu g}$} \\
\hline & MJ & kcal & g & $\% \mathrm{E}$ & $g$ & $\% \mathrm{E}$ & g & $\% \mathrm{E}$ & $\mathrm{g}$ & $\% \mathrm{E}$ & & & & & \\
\hline \multicolumn{16}{|l|}{ Male (5 years) } \\
\hline $\begin{array}{l}\text { Moderately active } \\
\text { Female ( } 9 \text { years) }\end{array}$ & $5 \cdot 9$ & 1408 & $47 \cdot 9$ & $30 \cdot 6$ & $15 \cdot 3$ & $9 \cdot 7$ & $64 \cdot 1$ & $18 \cdot 2$ & $192 \cdot 4$ & $51 \cdot 2$ & $10 \cdot 2$ & $14 \cdot 4$ & $8 \cdot 3$ & 950 & $1 \cdot 5$ \\
\hline $6 \cdot 7 \mathrm{MJ}(1600 \mathrm{kcal})$ & & & & & & & & & & & & & & & \\
\hline $\begin{array}{l}\text { Moderately active } \\
\text { Male (10 years) }\end{array}$ & $6 \cdot 7$ & 1611 & $50 \cdot 8$ & $28 \cdot 4$ & $17 \cdot 6$ & $9 \cdot 8$ & $77 \cdot 5$ & $19 \cdot 2$ & $225 \cdot 5$ & $52 \cdot 3$ & $9 \cdot 1$ & $16 \cdot 9$ & $12 \cdot 2$ & $1013 \S$ & $2 \cdot 9$ \\
\hline $7 \cdot 5 \mathrm{MJ}(1800 \mathrm{kcal})$ & & & & & & & & & & & & & & & \\
\hline $\begin{array}{l}\text { Moderately active } \\
\text { Female ( } 9 \text { years) } \\
8.4 \mathrm{MJ}(2000 \mathrm{kcal})\end{array}$ & $7 \cdot 6$ & 1811 & $61 \cdot 6$ & $30 \cdot 6$ & $17 \cdot 9$ & $8 \cdot 9$ & $82 \cdot 0$ & $18 \cdot 1$ & $248 \cdot 0$ & $51 \cdot 2$ & $6 \cdot 4$ & $21 \cdot 2$ & $12 \cdot 6$ & $1178 \S$ & $1 \cdot 6$ \\
\hline $\begin{array}{l}8 \cdot 4 \mathrm{MJ}(2000 \mathrm{kcal}) \\
\text { Moderately active } \\
\text { Male (10 years) }\end{array}$ & $8 \cdot 3$ & 1993 & $72 \cdot 1$ & $32 \cdot 5$ & $22 \cdot 4$ & $10 \cdot 1$ & $87 \cdot 3$ & $17 \cdot 5$ & $265 \cdot 9$ & $49 \cdot 9$ & $10 \cdot 5$ & $19 \cdot 9$ & $13 \cdot 8$ & $1141 \S$ & $2 \cdot 0$ \\
\hline $\begin{array}{l}9 \cdot 2 \mathrm{MJ}(2200 \mathrm{kcal}) \\
\text { Moderately active }\end{array}$ & $9 \cdot 2$ & 2202 & $79 \cdot 9$ & $32 \cdot 7$ & $21 \cdot 9$ & $9 \cdot 0$ & $88 \cdot 7$ & $16 \cdot 1$ & $301 \cdot 6$ & $51 \cdot 2$ & $7 \cdot 4$ & $23 \cdot 6$ & $14 \cdot 0$ & $1265 \|$ & $1 \cdot 7$ \\
\hline $\begin{array}{l}\text { Female (14-18 years) } \\
7.5 \mathrm{MJ}(1800 \mathrm{kcal})\end{array}$ & & & & & & & & & & & & & & & \\
\hline $\begin{array}{l}\text { Sedentary } \\
\text { Female (14-18 years) }\end{array}$ & $7 \cdot 5$ & 1784 & $56 \cdot 8$ & $28 \cdot 7$ & $18 \cdot 4$ & $9 \cdot 3$ & $94 \cdot 6$ & $21 \cdot 2$ & $239 \cdot 6$ & $50 \cdot 3$ & $7 \cdot 2$ & $17 \cdot 1$ & $12 \cdot 6$ & 1412 & $4 \cdot 0$ - \\
\hline $8.4 \mathrm{MJ}(2000 \mathrm{kcal})$ & & & & & & & & & & & & & & & \\
\hline $\begin{array}{l}\text { Moderately active } \\
\text { Male (14-18 years) } \\
9 \cdot 2 \mathrm{MJ} \text { (2200 kcal) }\end{array}$ & $8 \cdot 4$ & 2000 & $70 \cdot 4$ & $31 \cdot 7$ & $20 \cdot 8$ & $9 \cdot 4$ & $103 \cdot 8$ & $20 \cdot 8$ & $254 \cdot 9$ & $47 \cdot 7$ & $6 \cdot 2$ & $20 \cdot 1$ & $13 \cdot 4$ & 1481 & $4 \cdot 0$ - \\
\hline $\begin{array}{l}\text { Sedentary } \\
\text { Male (14-18 years) }\end{array}$ & $9 \cdot 2$ & 2204 & $65 \cdot 0$ & $26 \cdot 5$ & $22 \cdot 0$ & $9 \cdot 0$ & $98 \cdot 9$ & $17 \cdot 9$ & $325 \cdot 5$ & $54 \cdot 2$ & $9 \cdot 7$ & $24 \cdot 4$ & $16 \cdot 5$ & 1470 & $1 \cdot 7$ \\
\hline $10 \mathrm{MJ}(2400 \mathrm{kcal})$ & & & & & & & & & & & & & & & \\
\hline $\begin{array}{l}\text { Moderately active } \\
\text { Male (14-18 years) }\end{array}$ & $10 \cdot 1$ & 2405 & $83 \cdot 0$ & $31 \cdot 1$ & $27 \cdot 8$ & $10 \cdot 4$ & $102 \cdot 4$ & $17 \cdot 0$ & $332 \cdot 3$ & $50 \cdot 7$ & $9 \cdot 1$ & $24 \cdot 2$ & $15 \cdot 8$ & 1417 & $1 \cdot 7$ \\
\hline $11.7 \mathrm{MJ}(2800 \mathrm{kcal})$ & & & & & & & & & & & & & & & \\
\hline $\begin{array}{l}\text { Moderately active } \\
\text { Male (19-50 years) } \\
9 \cdot 2 \mathrm{MJ}(2200 \mathrm{kcal})\end{array}$ & $11 \cdot 7$ & 2796 & $94 \cdot 0$ & $30 \cdot 2$ & $34 \cdot 8$ & $11 \cdot 2$ & $117 \cdot 2$ & $16 \cdot 8$ & $378 \cdot 8$ & $49 \cdot 9$ & $8 \cdot 8$ & $27 \cdot 7$ & $17 \cdot 5$ & 1545 & $2 \cdot 0$ \\
\hline $\begin{array}{l}\text { Sedentary } \\
\text { Male (19-50 years) }\end{array}$ & $9 \cdot 2$ & 2196 & $62 \cdot 6$ & $25 \cdot 7$ & $18 \cdot 5$ & $7 \cdot 6$ & $105 \cdot 6$ & $19 \cdot 2$ & $322 \cdot 8$ & $54 \cdot 6$ & $7 \cdot 8$ & $28 \cdot 0$ & $14 \cdot 8$ & 1197 & $3 \cdot 3$ \\
\hline $10 \mathrm{MJ}(2400 \mathrm{kcal})$ & & & & & & & & & & & & & & & \\
\hline $\begin{array}{l}\text { Moderately active } \\
\text { Male (19-50 years) }\end{array}$ & $10 \cdot 0$ & 2399 & $69 \cdot 3$ & $26 \cdot 0$ & $21 \cdot 3$ & $8 \cdot 0$ & $114 \cdot 1$ & $19 \cdot 0$ & $351 \cdot 9$ & $54 \cdot 6$ & $8 \cdot 1$ & $28 \cdot 9$ & $16 \cdot 1$ & 1388 & $3 \cdot 3$ \\
\hline $10.9 \mathrm{MJ}(2600 \mathrm{kcal})$ & & & & & & & & & & & & & & & \\
\hline $\begin{array}{l}\text { Moderately active } \\
\text { Male (19-50 years) }\end{array}$ & $10 \cdot 9$ & 2594 & $85 \cdot 4$ & $29 \cdot 6$ & $26 \cdot 9$ & $9 \cdot 3$ & $112 \cdot 4$ & $17 \cdot 3$ & $367 \cdot 4$ & $52 \cdot 7$ & $9 \cdot 9$ & $30 \cdot 4$ & $16 \cdot 3$ & 1387 & $3 \cdot 4$ \\
\hline $11 \cdot 7 \mathrm{MJ}(2800 \mathrm{kcal})$ & & & & & & & & & & & & & & & \\
\hline $\begin{array}{l}\text { Moderately active } \\
\text { Female (19-50 years) }\end{array}$ & $11 \cdot 7$ & 2794 & $89 \cdot 0$ & $28 \cdot 7$ & $33 \cdot 3$ & $10 \cdot 7$ & $117 \cdot 5$ & $16 \cdot 8$ & $390 \cdot 7$ & $52 \cdot 1$ & $9 \cdot 5$ & $31 \cdot 6$ & $17 \cdot 3$ & 1487 & $3 \cdot 6$ \\
\hline 7·5 MJ (1800 kcal) & & & & & & & & & & & & & & & \\
\hline Sedentary & $7 \cdot 5$ & 1791 & $58 \cdot 3$ & $29 \cdot 3$ & $19 \cdot 5$ & $9 \cdot 8$ & 83.5 & $18 \cdot 6$ & $250 \cdot 2$ & $52 \cdot 2$ & $8 \cdot 7$ & $20 \cdot 0+$ & $13 \cdot 8$ & 1077 & $5 \cdot 5$ ब \\
\hline
\end{tabular}




\begin{tabular}{|c|c|c|c|c|c|c|c|c|c|c|c|c|c|c|c|}
\hline \multirow[b]{3}{*}{ Sub-population } & \multicolumn{15}{|c|}{ Energy and nutrient intakes } \\
\hline & \multicolumn{2}{|c|}{ Energy $^{*}$} & \multicolumn{2}{|c|}{ Total fat } & \multicolumn{2}{|c|}{ Saturated fat } & \multicolumn{2}{|c|}{ Protein } & \multicolumn{2}{|c|}{ Carbohydrate } & \multirow{2}{*}{$\frac{\mathrm{NMES}}{\% \mathrm{E}}$} & \multirow{2}{*}{$\frac{\text { Fibre }}{g}$} & \multirow{2}{*}{$\frac{\mathrm{Fe}}{\mathrm{mg}}$} & \multirow{2}{*}{$\begin{array}{c}\mathrm{Ca} \\
\mathrm{mg}\end{array}$} & \multirow{2}{*}{$\frac{\text { Vitamin D }}{\mu \mathrm{g}}$} \\
\hline & MJ & kcal & g & $\% \mathrm{E}$ & g & $\% \mathrm{E}$ & g & $\% \mathrm{E}$ & $\mathrm{g}$ & $\% \mathrm{E}$ & & & & & \\
\hline \multicolumn{16}{|l|}{$\begin{array}{l}\text { Female (19-50 years) } \\
8.4 \mathrm{MJ}(2000 \mathrm{kcal})\end{array}$} \\
\hline $\begin{array}{l}\text { Moderately active } \\
\text { Female (19-50 years) } \\
9 \cdot 2 \mathrm{MJ}(2200 \mathrm{kcal})\end{array}$ & $8 \cdot 3$ & 1991 & $70 \cdot 3$ & $31 \cdot 8$ & $22 \cdot 3$ & $10 \cdot 1$ & $87 \cdot 3$ & $17 \cdot 5$ & $270 \cdot 6$ & $50 \cdot 9$ & $8 \cdot 7$ & $22 \cdot 2 \dagger$ & $16 \cdot 5$ & 1107 & $5 \cdot 89$ \\
\hline $\begin{array}{l}\text { Moderately active } \\
\text { Male }(51+\text { years }) \\
8 \cdot 4 \mathrm{MJ}(2000 \mathrm{kcal})\end{array}$ & $9 \cdot 2$ & 2200 & $79 \cdot 8$ & $32 \cdot 6$ & $23 \cdot 8$ & $9 \cdot 7$ & $91 \cdot 4$ & $16 \cdot 6$ & $299 \cdot 1$ & $50 \cdot 9$ & $9 \cdot 6$ & $23 \cdot 4 t$ & $14 \cdot 3$ & 1147 & $5 \cdot 19$ \\
\hline $\begin{array}{l}\text { Sedentary } \\
\text { Male }(51+\text { years }) \\
9 \cdot 2 \mathrm{MJ}(2200 \mathrm{kcal})\end{array}$ & $8 \cdot 4$ & 2005 & $72 \cdot 6$ & $32 \cdot 3$ & $20 \cdot 4$ & $9 \cdot 1$ & $88 \cdot 2$ & $17 \cdot 5$ & $271 \cdot 0$ & $50 \cdot 2$ & $7 \cdot 9$ & $20 \cdot 9+$ & $13 \cdot 8$ & 1214 & $0 \cdot 7$ \\
\hline $\begin{array}{l}\text { Moderately active } \\
\text { Male }(51+\text { years }) \\
10 \mathrm{MJ}(2400 \mathrm{kcal})\end{array}$ & $9 \cdot 2$ & 2193 & $81 \cdot 2$ & $33 \cdot 3$ & $23 \cdot 0$ & $9 \cdot 4$ & $92 \cdot 7$ & $16 \cdot 9$ & $295 \cdot 6$ & $50 \cdot 5$ & $8 \cdot 3$ & $22 \cdot 1 \dagger$ & $14 \cdot 4$ & 1268 & $0 \cdot 7$ \\
\hline $\begin{array}{l}\text { Moderately active } \\
\text { Female (51+ years) } \\
6 \cdot 7 \mathrm{MJ}(1600 \text { kcal })\end{array}$ & 10 & 2392 & $94 \cdot 0$ & $35 \cdot 4$ & $26 \cdot 9$ & $10 \cdot 1$ & $102 \cdot 9$ & $17 \cdot 2$ & $308 \cdot 0$ & $48 \cdot 2$ & $7 \cdot 8$ & $24 \cdot 5+$ & $15 \cdot 7$ & 1334 & $1 \cdot 1$ \\
\hline $\begin{array}{l}\text { Sedentary } \\
\text { Female }(51+\text { years }) \\
7.5 \mathrm{MJ}(1800 \text { kcal })\end{array}$ & $6 \cdot 7$ & 1597 & $48 \cdot 2$ & $27 \cdot 2$ & $14 \cdot 2$ & $8 \cdot 0$ & $78 \cdot 2$ & $19 \cdot 6$ & $228 \cdot 1$ & $53 \cdot 4$ & $11 \cdot 5$ & $15 \cdot 7 \ddagger$ & $8 \cdot 7$ & 1127 & $1 \cdot 6$ \\
\hline Moderately active & $7 \cdot 6$ & 1806 & $63 \cdot 8$ & $31 \cdot 8$ & $18 \cdot 2$ & $9 \cdot 1$ & $81 \cdot 9$ & $18 \cdot 1$ & $242 \cdot 5$ & $50 \cdot 3$ & $10 \cdot 9$ & $16 \cdot 9 \ddagger$ & $9 \cdot 6$ & 1173 & $1 \cdot 8$ \\
\hline
\end{tabular}

NMES, non-milk extrinsic sugars; \%E, percentage of energy intake.

*Estimated energy requirements for sedentary and moderate levels of physical activity, based on the Institute of Medicine (IOM) recommendations for reference sized individuals ${ }^{(21)}$. 'Reference size' is based on median height and weight for ages up to age 18 years; and, for adults, median height and weight for that height to give a BMI of $21.5 \mathrm{~kg} / \mathrm{m}^{2}$ for females and $22.5 \mathrm{~kg} / \mathrm{m}^{2}$ for males. 'Moderately active' is described as a lifestyle that includes physical activity equivalent to walking about 1.5 to 3 miles $/ \mathrm{d}$ at $3-4 \mathrm{miles} / \mathrm{h}$, in addition to the light physical activity associated with typical day-to-day life. 'Sedentary' means a lifestyle that includes only the light physical activity associated with typical day-to-day life.

tThe females requiring $8.4 \mathrm{MJ}(2000 \mathrm{kcal})$ and $9 \cdot 2 \mathrm{MJ}(2200 \mathrm{kcal})$, as well as the male aged $51+$ years requiring $9 \cdot 2-10 \cdot 0 \mathrm{MJ}(2200-2400$

tThe food intake pattern for the adult female aged $51+$ years requing $75 \mathrm{MJ}(1800 \mathrm{kcal})$ achieved $68 \%$ of the

$\S$ The IOM recommends an Adequate Intake (AI) of $1300 \mathrm{mg} \mathrm{Ca}$ from 9 to 18 years ${ }^{(25)}$. Ca intakes did not reach the goals for 9-10-year-olds due to their lower energy requirements, with the exception of the food intake pattern for the 10-year-old boy.

\|Requiring $9.2 \mathrm{MJ}(2200 \mathrm{kcal})$, who achieved $97 \%$ of his $\mathrm{Al}$ for $\mathrm{Ca}$.

- The food intake pattern for girls aged $14-18$ years, both at $7.5 \mathrm{MJ}(1800 \mathrm{kcal})$ and $8.4 \mathrm{MJ}(2000 \mathrm{kcal})$, included one portion $(150 \mathrm{~g})$ of oily fish, and the diet patterns for the women aged $19-50$ years requiring $7.5,8.4$ and $9 \cdot 2 \mathrm{MJ}(1800,2000$ and $2200 \mathrm{kcal})$ included servings of oily fish at both one main meal $(150 \mathrm{~g})$ and one light meal $(50 \mathrm{~g})$. 
Table 2 Recommended number of daily servings from each of the main food groups for healthy eating for males and females representative of Ireland's population aged 5 years and older

\begin{tabular}{|c|c|c|c|c|c|c|c|c|}
\hline \multirow{3}{*}{$\begin{array}{l}\text { Age (years) } \\
\text { Gender }\end{array}$} & \multicolumn{2}{|c|}{ Children } & \multicolumn{2}{|c|}{ Teenagers } & \multicolumn{2}{|c|}{ Adults } & \multicolumn{2}{|c|}{ Adults } \\
\hline & \multicolumn{2}{|c|}{$5-13$} & \multicolumn{2}{|c|}{$14-18$} & \multicolumn{2}{|c|}{$19-50$} & \multicolumn{2}{|c|}{$51+$} \\
\hline & Male & Female & Male & Female & Male & Female & Male & Female \\
\hline Range of energy requirements* & & & & & & & & \\
\hline $\begin{array}{l}\mathrm{MJ} \\
\mathrm{kcal}\end{array}$ & $\begin{array}{c}5 \cdot 9-9 \cdot 2 \\
1400-2200\end{array}$ & $\begin{array}{c}5 \cdot 9-8 \cdot 4 \\
1400-2000\end{array}$ & $\begin{array}{r}9 \cdot 2-11 \cdot 7 \\
2200-2800\end{array}$ & $\begin{array}{c}7 \cdot 5-8 \cdot 4 \\
1800-2000\end{array}$ & $\begin{array}{r}9 \cdot 2-10 \cdot 8 \\
2200-2600\end{array}$ & $\begin{array}{c}7 \cdot 5-9 \cdot 2 \\
1800-2200\end{array}$ & $\begin{array}{r}8 \cdot 4-10 \cdot 0 \\
2000-2400\end{array}$ & $\begin{array}{c}6 \cdot 7-7 \cdot 5 \\
1600-1800\end{array}$ \\
\hline \multicolumn{9}{|l|}{ Bread, Cereal and Potato group } \\
\hline Moderately active & $3-5$ & $3-4$ & $5-7$ & 4 & $5-7$ & $4-5$ & $4-5$ & $3-4$ \\
\hline Sedentaryt & & & $4-5$ & 3 & $4-6$ & $3-4$ & 4 & 3 \\
\hline Fruit and Vegetables group & 5 & 5 & $5-6$ ฯ & 5 & $5-79$ & $5-6$ ฯ & 5 & 5 \\
\hline Milk, Yoghurt and Cheese group & $3-5^{\star \star}$ & $3-5^{\star \star}$ & 5 & 5 & $3-5+t$ & 3 & 3 & 3 \\
\hline \multicolumn{9}{|l|}{ Meat, Fish and Alternatives group } \\
\hline Larger serving & 1 & 1 & 1 & 1 & 1 & 1 & 1 & 1 \\
\hline Smaller serving & 1 & 1 & $1-2 \ddagger \ddagger$ & 1 & $1-2 \ddagger \ddagger$ & 1 & 1 & 1 \\
\hline
\end{tabular}

Fat Spreads and Oils

Choose reduced-fat unsaturated spreads where possible. One portion pack§ of reduced-fat poly- or monounsaturated spread is more than enough for one slice of bread - try to make it do for two. Unsaturated oils are better than solid fats but are just as fattening! Choose cooking methods such as grilling or baking more often. When oil is used in cooking, use sparingly!

Other Foods These foods are high in calories, fat, sugar and salt and need to be limited - you can enjoy healthy eating without them

Sugar can be used sparingly to sweeten high-fibre nutritious foods such as stewed fruit and wholegrain cereals, e.g. porridge. Jams, marmalades and honey can sometimes replace fat spreads on wholemeal bread.

Cakes, biscuits, savoury snacks and confectionery are high in fats (saturated fat and possibly trans fats\$), sugar, salt and calories, which should be limited to 'sometimes but not every day'.ll

${ }^{*}$ Estimated energy requirements for moderate levels of physical activity, based on the Institute of Medicine recommendations for reference sized individuals ${ }^{(21)}$. 'Reference size' is based on median height and weight for ages up to age 18 years of age; and, for adults, median height and weight for that height to give a BMI of $21.5 \mathrm{~kg} / \mathrm{m}^{2}$ for females and $22 \cdot 5 \mathrm{~kg} / \mathrm{m}^{2}$ for males. 'Moderately active' is described as a lifestyle that includes physical activity equivalent to walking about 1.5-3 miles/d at 3-4 miles/ $h$, in addition to the light physical activity associated with typical day-to day life. 'Sedentary' means a lifestyle that includes only the light physical activity associated with typical day-to-day life.

tFood intake patterns providing energy requirements for sedentary levels of physical activity were devised for those aged 14 to $51+$ years only

‡'Larger serving' refers to the serving to be eaten at a main meal; 'Smaller serving' refers to the serving to be eaten at a light meal.

One portion pack of fat spread contains $7-10 \mathrm{~g} .60 \%$ monounsaturated and polyunsaturated spreads and unsaturated oils were used in the food patterns.

IIFoods such as ice cream, popcorn and apple pie were used occasionally in the diet patterns of those with energy requirements of $9 \cdot 2 \mathrm{MJ}$ (2200 kcal) or more, and ice cream was included in the patterns for children. No alcohol was included.

More than 5 servings were used in higher energy food patterns.

${ }^{* *}$ Children from 9 years of age require up to 5 servings/d to reach the Adequate Intake (Al) of $1300 \mathrm{mg} / \mathrm{d}^{(25)}$.

t+Moderately active males aged 14-50 years may choose up to 5 servings to meet energy requirements.

\#¥Moderately active males aged 14-50 years with the highest energy requirements may have an extra 'smaller serving' from this food group.

. However, in the absence of specific regulations that label, or restrict, levels of

industrialized trans fat in foods, 
Table 3 Description of final serving sizes (average food weight) of foods from the Bread, Cereal and Potato Group sub-categorized according to energy content

\begin{tabular}{|c|c|c|c|}
\hline $418-565 \mathrm{~kJ}(100-135 \mathrm{kcal})$ & $565-669 \mathrm{~kJ}(135-160 \mathrm{kcal})$ & $669-795$ kJ (160-190 kcal) & 795-921 kJ (190-220 kcal) \\
\hline $1 / 3$ cup$^{*}$ raw porridge oats $(30 \mathrm{~g}) \dagger$ & $\begin{array}{l}\text { Two wholegrain cereal } \\
\text { biscuits }(40 \mathrm{~g})\end{array}$ & $1 / 2$ cup* muesli $(43 \mathrm{~g})$ & \\
\hline $\begin{array}{l}\text { One cup* wholemeal cereal } \\
\text { flakes }(40 \mathrm{~g})\end{array}$ & & & $\begin{array}{l}11 / 2 \text { cups* wholemeal cereal } \\
\text { flakes }(60 \mathrm{~g})\end{array}$ \\
\hline $\begin{array}{l}\text { One slice soda wholemeal } \\
\text { bread }(44 \mathrm{~g})\end{array}$ & $\begin{array}{l}\text { Two regular slices wholemeal } \\
\text { pan bread }(70 \mathrm{~g})\end{array}$ & One tortilla wrap $(58 \mathrm{~g})$ & $\begin{array}{l}2 \text { 'thick cut' slices wholemeal } \\
\text { pan bread }(92 \mathrm{~g})\end{array}$ \\
\hline $\begin{array}{l}\text { One slice wholemeal batch loaf } \\
\quad(56 \mathrm{~g})\end{array}$ & $\begin{array}{l}\text { One wholemeal pita } \\
\text { bread }(60 \mathrm{~g})\end{array}$ & $\begin{array}{c}5 \text { inch }(13 \mathrm{~cm}) \text { baguette roll } \\
\text { (approximately } 0.5 \text { lunch } \\
\text { size baguette roll) }(68 \mathrm{~g})\end{array}$ & One bagel $(79 \mathrm{~g})$ \\
\hline $\begin{array}{l}\text { One medium wholemeal bread } \\
\text { roll }(50 \mathrm{~g})\end{array}$ & & $1 / 2$ panini bread $(64 \mathrm{~g})$ & \\
\hline $\begin{array}{l}\text { Four wholemeal crispbread }(40 \mathrm{~g}) \text { or } \\
\text { crackers }(28 \mathrm{~g})\end{array}$ & & $1 / 2$ ciabatta roll $(63 \mathrm{~g})$ & \\
\hline \multicolumn{4}{|l|}{$\begin{array}{l}\text { One medium-sized boiled or baked } \\
\text { potato }(180 \mathrm{~g})\end{array}$} \\
\hline Three scoops potato mash $(180 \mathrm{~g})$ & $\begin{array}{l}\text { One cup }{ }^{*} \text { cooked basmati } \\
\text { rice }(105 \mathrm{~g})\end{array}$ & $\begin{array}{l}1 \text { cup* cooked 'easy cook' } \\
\text { white rice }(116 \mathrm{~g})\end{array}$ & $\begin{array}{l}\text { One cup* cooked brown rice } \\
(146 \mathrm{~g})\end{array}$ \\
\hline $\begin{array}{l}\text { One cup }{ }^{\star} \text { cooked pasta } \\
\text { shapes }(103 \mathrm{~g})\end{array}$ & $\begin{array}{l}\text { One cup* cooked white } \\
\text { spaghetti }(139 \mathrm{~g})\end{array}$ & $\begin{array}{l}1 \text { cup }^{\star} \text { cooked brown spaghetti } \\
(140 \mathrm{~g})\end{array}$ & \\
\hline
\end{tabular}

${ }^{*}$ Cup used to describe serving size was a $200 \mathrm{ml}$ plastic disposable cup.

tServing of porridge oats described given as uncooked. Energy value given for corresponding cooked porridge made with water.

Table 4 Key recommendations for healthy eating in Ireland based on the development of food-based dietary guidelines

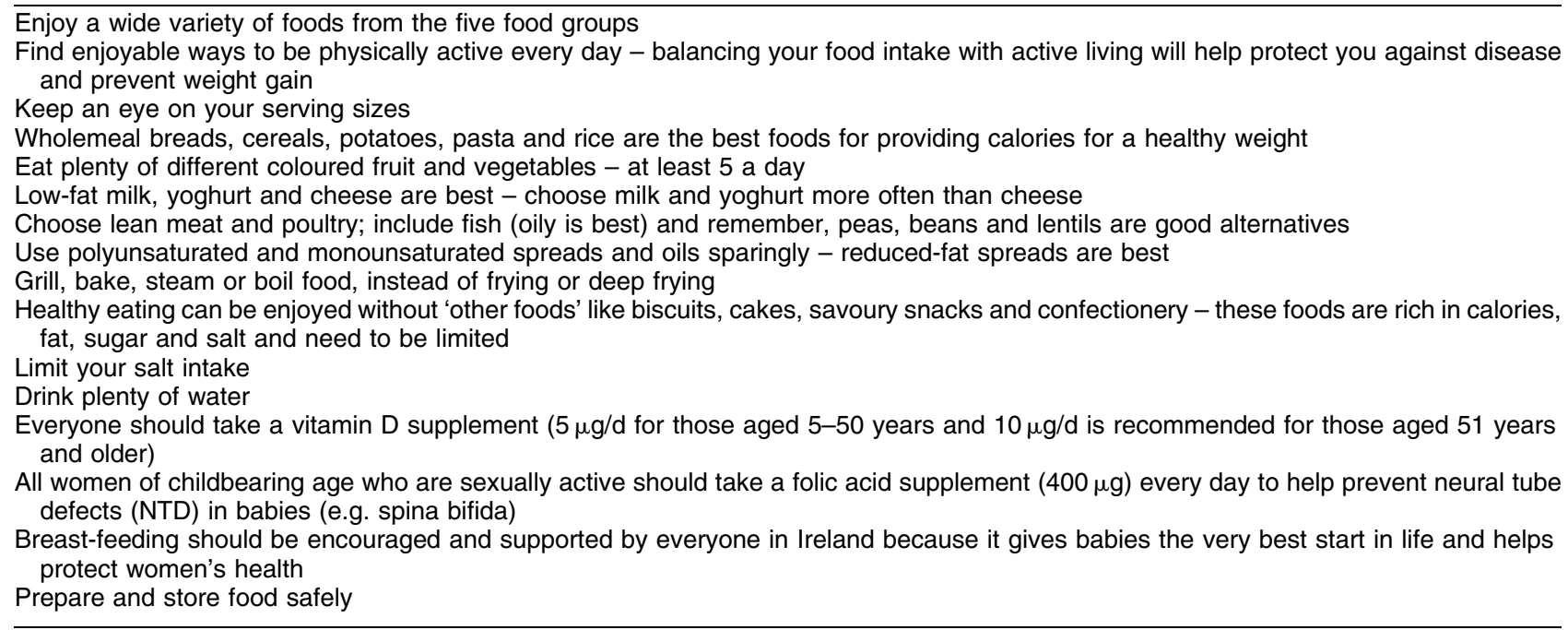

that sugar and preserves can be used sparingly to sweeten high-fibre foods such as porridge and wholemeal bread aims to address the challenge of achieving fibre goals without increasing fat intakes. This was found to be particularly relevant for subgroups with lower energy requirements, where fibre goals are difficult to achieve.

Given the increasing rates of obesity in Ireland ${ }^{(3-6)}$, guidance on energy was incorporated into healthy eating advice, which follows the approach used in recent revisions of food guides in other countries ${ }^{(17,34)}$. The energy requirements set were for people of normal body weight ${ }^{(21)}$, which means that overweight people following the guidance on food servings will tend to lose weight. For health promotion and disease prevention, being moderately active is strongly recommended ${ }^{(35,36)}$. However, the only available data for levels of activity among people living in Ireland suggest that almost one in five adults is sedentary (i.e. report 'taking no exercise $\left.{ }^{(37)}\right)$. As self-reported estimates of physical activity may be subject to reporting error ${ }^{(38,39)}$, the number of people in Ireland who are sedentary may be underestimated. It was therefore deemed necessary to include advice for energy requirements at sedentary levels of physical activity. This approach has the advantage of also providing guidance for moderately active people on how they need to adapt their energy intakes during periods of 


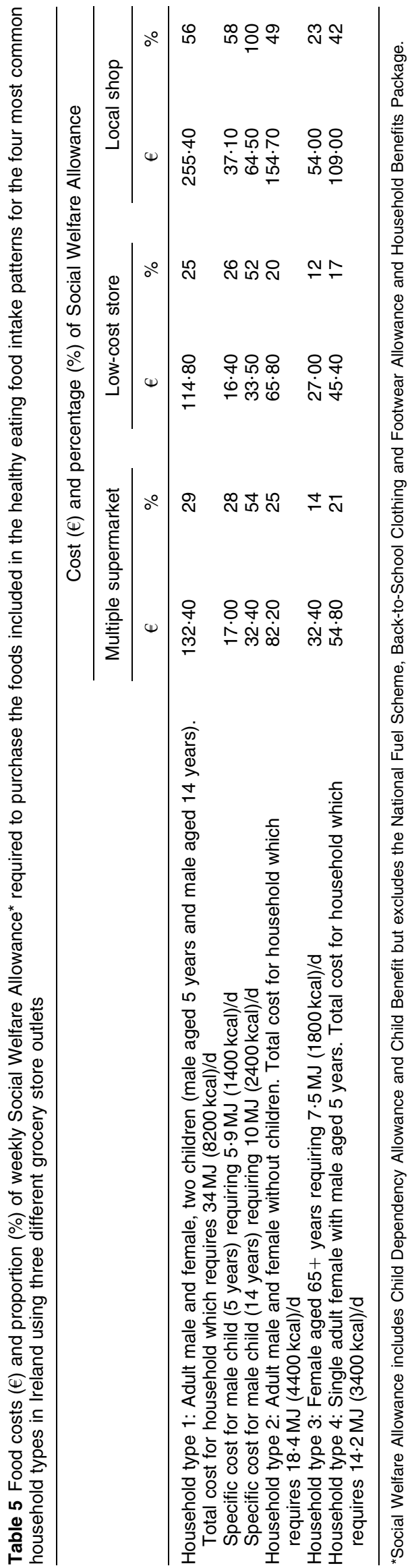

inactivity, thus preventing unintentional weight gain. No advice for very active people, as defined by the Institute of Medicine ${ }^{(21)}$, was included because the needs of this subgroup were recognized as being heterogeneous and general guidance on healthy eating may not cover their needs appropriately.

Foods from the Bread, Cereal and Potato group were the main focus of energy guidance because these foods impact on the acceptable macronutrient distribution range ${ }^{(21)}$. It was deemed important to alert consumers to the range of relative energy content of these foods, e.g. $460 \mathrm{~kJ}$ (110 kcal) for porridge $v .920 \mathrm{~kJ}$ (220 kcal) for a bagel. Without this sub-categorization, consumers could potentially believe that these critical foods for energy balance were equivalent.

The goal for $\mathrm{Ca}$ intakes in children aged 9-10 years $(1300 \mathrm{mg} / \mathrm{d})$ was difficult to attain and it was therefore recommended that daily servings of low-fat dairy foods may need to be increased due to the onset of puberty. Recent research shows that vitamin D intakes are very low in most age groups in Ireland ${ }^{(40-42)}$. Such poor vitamin D intakes are further compounded by Ireland's northerly latitude and temperate climate ${ }^{(43,44)}$ and, as such, inadequate vitamin D status is evident in many subgroups ${ }^{(45,46)}$. Ireland's latitude is comparable with the main populated areas of Canada where all milk is fortified with vitamin D on a mandatory basis. In addition to this, Health Canada recommends that all adults over 50 years take supplements providing $10 \mu \mathrm{g}$ vitamin D daily ${ }^{(34)}$. In this revision the only adjusted food patterns that provided an adequate intake of vitamin D included oily fish twice in four days, which is not reflective of eating habits in Ireland. Preliminary recommendations therefore include daily supplements $(5 \mu \mathrm{g}$ vitamin D for 5-50 years and $10 \mu \mathrm{g}$ for 51 years and older). Given the preventive role of vitamin D in osteoporosis and its emerging role in the prevention of many chronic diseases ${ }^{(43)}$, it has been suggested by some researchers that the current recommendations for daily intakes of vitamin D are not adequate ${ }^{(47-49)}$. In relation to this the Institute of Medicine has recently revised its vitamin D intake recommendations, substantially increasing its previous dietary reference intakes for vitamin $\mathrm{D}^{(50)}$. In Ireland, therefore, an expert group will be required to review and implement the most appropriate strategies for vitamin D supplementation in different subgroups of the Irish population.

To achieve the goal for saturated fat significant readjustments to food patterns were required involving use of low-fat dairy foods, unsaturated fat spreads and oils and lean meats. Food patterns developed for males with higher daily energy requirements of $10 \cdot 0-11 \cdot 7 \mathrm{MJ}$ $(2400-2800 \mathrm{kcal})$ that included occasional foods from the Other Foods group and some full-fat dairy products tended to exceed the $\leq 10 \%$ of energy goal. Since males have a relatively high risk of developing $\mathrm{CVD}^{(51)}$, it can be concluded that the best advice for everyone involves 
limiting 'other foods' and preferential use of low-fat dairy products, as well as unsaturated spreads and oils and lean meats. Such guidelines are in line with recently developed healthy eating guidelines in Australia ${ }^{(52)}$, Canada $^{(34)}$ and the USA ${ }^{(17)}$.

This revision found that fibre goals were difficult to achieve, as previously reported in Ireland ${ }^{(53)}$, particularly in food patterns that were based on lower energy requirements $(<10 \mathrm{MJ} /<2400 \mathrm{kcal})$. Specific adjustments of food patterns involved the sparing use of two fat-free sources of sugar, i.e. table sugar and preserves, to increase the acceptability and palatability of fibre-rich food sources, such as wholemeal cereals, breads and stewed fruit - an approach that has been previously used ${ }^{(52,54)}$. However this revision of healthy eating advice also includes advice to avoid frequent intakes of sugar for the promotion of good dental health ${ }^{(55)}$. Previous work in Ireland has highlighted an inverse relationship between intakes of saturated fat and sugar and preserves ${ }^{(56)}$ and the inverse relationship between sugar and fat intakes is well established ${ }^{(57,58)}$. Notwithstanding this, the inclusion of sugar and sugary foods for their own sake (i.e. independent of fibre-rich foods) was not supported in this revision. Consumption of sugary foods, such as soft drinks, or sugary foods that also contain fat, such as confectionery, increases intakes of energy and possibly fat without providing essential nutrients ${ }^{(15)}$, and high-fat sweet foods may be positively associated with obesity ${ }^{(59)}$. Therefore, in addition to management of saturated fat intakes discussed above, limiting intake of these 'other foods' is also emphasized in this revision to allow for increased intake of more nutrientdense food sources of energy, such as fibre-rich breads and cereals. A similar approach is taken in the recently updated dietary guidelines for Americans of all ages, where consumption of energy from solid fats (fats containing a high proportion of saturated and trans fatty acids) and added sugars is recommended to be kept 'as low as possible' to allow for increased intake of nutrient-dense foods without exceeding overall energy needs ${ }^{(60)}$. In relation to trans fats, reformulation of the Irish food supply in recent years has led to a substantial reduction in the level of industrialized trans fat ${ }^{(61,62)}$. However, in the absence of specific regulations that label or restrict levels of industrialized trans fat in foods, consumers are advised that some foods in the Other Foods group, previously identified to be significant sources of such fats ${ }^{(63)}$, may contain trans fats.

The present study found that the cost of healthy eating accounts for approximately one-third of the social welfare allowance in Ireland and is more expensive for families with children, especially those with older children. Older children need more food to cover the high energy and nutrients required to support their growth and development throughout adolescence ${ }^{(21,25)}$. However, child benefit and social welfare payments in Ireland do not take account of this. For example, the entire weekly social welfare allowance for the adolescent male only just covers the cost of healthy eating if all shopping is carried out in a 'local' store. Local convenience shops were found to be almost twice as expensive for healthy eating. It is known that access to cheaper grocery stores can be difficult for many families on low income due to reliance on public transport ${ }^{(19,20)}$. The finding that foods promoted for healthy eating such as fruit and vegetables and lean meat alternatives are relatively much more expensive is supported by other studies ${ }^{(13,14,20)}$. This barrier to healthy eating needs to be addressed as it is likely to contribute to the higher risk of diet-related diseases among those who are socially disadvantaged or on lower incomes ${ }^{(11,12)}$. Such work could focus on the development of healthy eating advice using cheaper food options (e.g. pulses and eggs as a cheaper alternative to meat) accompanied by community-based practical activities (e.g. meal planning, shopping and preparing meals on a budget).

The use of dietary databases to generate food patterns for healthy eating guidelines, as used in the USA ${ }^{(16)}$, has the clear advantage of being based on prevailing eating habits, engendering greater confidence in the potential acceptability of the resulting guidelines. Unfortunately this approach was beyond the scope and resources of this current revision. However, constructing the food patterns using foods 'typically eaten' (according to national nutrition surveys ${ }^{(27-29)}$ ), and involving nutritionists and dietitians experienced in assessing dietary intakes among various age and gender groups in Ireland, helped to provide food patterns that were largely reflective of mainstream eating habits in Ireland. It is recognized, however, that this is but a first step in providing guidance on healthy food choice due to the countless different food combinations that can make up a healthy diet. Nevertheless, for the prevention of obesity and chronic disease in Ireland, the most pertinent aspects of the food guide requiring revision were addressed in that the revised guidelines outline how nutrient goals can be achieved within energy requirements. In addition, guidance is provided which aims to reduce saturated fat, increase fibre and provide adequate vitamin D intakes. Further work is required that focuses on foods favoured by various subgroups of the population (e.g. teenagers $v$. older adults) and the development of the most appropriate form of communication (e.g. wording and graphic model).

These revised food-based dietary-guidelines need to be promoted in tandem with the recent national guidelines that recommend more physical activity in Ireland ${ }^{(64)}$. The higher food intakes required to cover the extra energy expenditure associated with increased physical activity may provide more scope for individuals with low energy requirements to achieve adequate intakes of nutrients such as fibre and Ca. Finally, even small changes towards healthier habits in both diet and physical activity can be effective at addressing the spiralling rates of overweight and obesity evident in Ireland over recent years ${ }^{(65)}$, especially in children and youth ${ }^{(66)}$. 


\section{Acknowledgements}

The work reported in this manuscript was funded by the Food Safety Authority of Ireland (FSAI). There are no conflicts of interest. The contributions of each author to the submitted manuscript are as follows. M.A.T.F.: research design, overall supervision and co-author of the manuscript; C.M.O'B. main researcher on all aspects of this work, supervision of research assistants, co-author of manuscript; V.R.: research assistant on assessment of the affordability of healthy eating and contributor to manuscript write-up; C.A.F.: research assistant on development and analysis of the food intake patterns and contributor to manuscript; S.J.B.: research assistant on assessment of the affordability of healthy eating and contributor to manuscript. We gratefully acknowledge the following dietitians who provided guidance on acceptable food patterns for children and older people: Ita Saul and Nicola Harris (Our Lady's Children's Hospital, Dublin); Valerie Kelly and dietetic colleagues (Children's University Hospital, Dublin); and Pauline Dunne and Grainne Flanagan (Older Person's Services, Midlands Health Service Executive). Special thanks are due to Margot Brennan, who coordinated feedback from members of the Irish Nutrition and Dietetic Institute. The advice and input of Members of the Steering Committee on Revision of the Food Based Dietary Guidelines for Ireland, FSAI, are also gratefully acknowledged. Finally many thanks are due to the administrative staff at the FSAI who helped to format and prepare the manuscript: Aileen Ward, Alice Kenny, Nicola Canning, Niamh Devaney and Marianne McFeely.

\section{References}

1. European Food Safety Authority Panel on Dietetic Products, Nutrition and Allergies (2010) Scientific opinion on establishing food-based dietary guidelines. EFSA J 8, 1460.

2. Johnson RK \& Kennedy E (2000) The 2000 Dietary Guidelines for Americans: what are the changes and why were they made? The Dietary Guidelines Committee. $J$ Am Diet Assoc 100, 769-774.

3. McCarthy SN, Harrington KE, Kiely M et al. (2001) Analyses of the anthropometric data from the North/South Ireland food consumption survey. Public Health Nutr 4, 1099-1106.

4. O'Neill JL, McCarthy SN, Burke SJ et al. (2007) Prevalence of overweight and obesity in Irish schoolchildren, using four different definitions. Eur J Clin Nutr 61, 743-751.

5. Whelton H, Harrington J, Crowley E et al. (2007) Prevalence of overweight and obesity on the island of Ireland: results from the North South Survey of Children's Height, Weight and Body Mass Index 2002. BMC Public Health 7, 187.

6. O'Neil JL, Boylan E, Burke SJ et al. (2009) Prevalence of obesity in Irish adolescents. Proc Nut Soc 67, E288.

7. Central Statistics Office (2006) Vital Statistics 4th Quarter and Yearly Summary 2005. Dublin: Central Statistics Office; available at http://www.cso.ie/newsevents/pressrelease_ vitalstatisticsq4andyear2005.htm

8. National Cancer Registry of Ireland (2010) Incidence, mortality, treatment and survival. http://www.ncri.ie/news/ 20090424.shtml (accessed September 2010).
9. Health Service Executive, Department of Health and Children \& National Council on Aging and Older People (2008) Strategy to prevent falls and fractures in Ireland's ageing population. http://www.hse.ie/eng/services/newscentre/2008_Archive/ Aug_2008/Preventing_Falls_and_Fractures.html (accessed May 2011).

10. Central Statistics Office (2010) Labour Market - Principal statistics. http://www.cso.ie/statistics/sasunemprates.htm (accessed September 2010).

11. Nelson M (2000) Childhood poverty and nutrition. Proc Nutr Soc 59, 307-315.

12. James WPT, Nelson M, Ralph A et al. (1997) Socioeconomic determinants of health: the contribution of nutrition to inequalities in health. BMJ 314, 1545-1549.

13. Drewnowski A \& Specter SE (2004) Poverty and obesity: the role of energy density and energy costs. Am J Clin Nutr 79, 6-16.

14. Drewnowski A \& Darmon N (2005) The economics of obesity: dietary energy density and energy cost. Am J Clin Nutr 82, 1 Suppl., 265S-273S.

15. Flynn MAT, O'Brien CM, Faulkner G et al. (2010) Revision of food-based dietary guidelines for Ireland, Phase I: evaluation of Ireland's food guide. Public Health Nutr (Epublication ahead of print version).

16. Britten P, Marcoe K, Yamini S et al. (2006) Development of food intake patterns for the MyPyramid Food Guidance System. J Nutr Educ Behav 38, 6 Suppl., S78-S92.

17. US Department of Health and Human Services \& US Department of Agriculture (2005) Dietary Guidelines for Americans. Washington, DC: USDA.

18. Central Statistics Office (2010) Survey on Income and Living Conditions (SILC) 2009. Dublin: Stationery Office; available at http://www.cso.ie/releasespublications/documents/silc/ current/silc.pdf

19. Kelleher CC, Lotya J, O'Hara MC et al. (2008) Session 1: Public health nutrition. Nutrition and social disadvantage in Ireland. Proc Nutr Soc 67, 363-370.

20. Friel S, Kelleher CC, Nolan G et al. (2005) Social diversity of Irish adults' nutritional intake. Eur J Clin Nutr 57, $865-875$.

21. Institute of Medicine (2002) Dietary Reference Intakes. Macronutrients Report. Washington, DC: National Academies Press.

22. Irish Heart Foundation (2007) Nutrition Guidelines for Heart Health with policy recommendations. http://www.irishheart. ie/media/pub/positionstatements/final_nutrition_guidelines 2007.pdf (accessed May 2011).

23. Williams CL, Bollela N \& Wynder EL (1995) A new recommendation for dietary fiber in childhood. Pediatrics 96, 985-988.

24. Norden (2004) Nordic Nutrition Recommendations: Integrating Nutrition and Physical Activity, 4th ed. Copenhagen: Nordic Council of Ministers.

25. Institute of Medicine (1997) Adequate Intakes (AIs) for calcium and vitamin D. In Dietary Reference Intakes for Calcium, Phosphorus, Magnesium, Vitamin D and Fluoride. Washington, DC: National Academies Press.

26. Department of Health, Committee on Medical Aspects of Food Policy (1989) Report on Dietary Sugars and Human Disease. London: HMSO.

27. Irish Universities Nutrition Alliance (2011) National Adult Nutrition Survey - summary report 2011. http://www.iuna.net/ wp-content/uploads/2010/12/National-Adult-Nutrition-SurveySummary-Report-March-2011.pdf (accessed May 2011).

28. Irish Universities Nutrition Alliance (2007) National Teens' Food Survey (2005-2006). http://www.iuna.net/?p=29 (accessed May 2011).

29. Irish Universities Nutrition Alliance (2005) National Children's Food Survey (2003-2004). http://www.iuna.net/ $? \mathrm{p}=27$ (accessed May 2011). 
30. Kelly S, Summerbell C, Rugg-Gunn AJ et al. (2005) Comparison of methods to estimate non-milk extrinsic sugars and their application to sugars in the diets of young adolescents. Br J Nutr 93, 114-124.

31. Ross VM, O'Brien CM, Burke SJ et al. (2009) How affordable is healthy eating? Proc Nutr Soc 68, E107.

32. Central Statistics Office (2010) Consumer Price Index Detailed Sub-Indices (November 2010). http://www.cso.ie/releases publications/documents/prices/2010/Prices/cpisubindices/pic_ nov2010.pdf (accessed January 2010).

33. Department of Finance (2010) The Budget - Summary of budget measures and policy changes. http://www.budget.gov. ie/budgets/2010/Summary.aspx (accessed January 2010).

34. Health Canada (2007) Eating Well with Canada's Food Guide. Ottawa: Health Canada; available at http:// www.healthcanada.gc.ca/foodguide

35. Pate RR, Pratt M, Blair SN et al. (1995) Physical activity and public health. A recommendation from the Centers for Disease Control and Prevention and the American College of Sports Medicine. JAMA 273, 402-407.

36. Haskell WL, Lee IM, Pate RR et al. (2007) Physical activity and public health: updated recommendations for adults from the American College of Sports Medicine and the American Heart Association. Med Sci Sports Exerc 89, 1423-1434.

37. Morgan K, McGee H, Watson D et al. (2008) SLAN 2007: Survey of Lifestyle, Attitudes and Nutrition in Ireland. Main Report. Dublin: Department of Health and Children.

38. Neilson HK, Robson PJ, Friedenreich CM et al. (2008) Estimating activity energy expenditure: how valid are physical activity questionnaires? Am J Clin Nutr 87, 279-291.

39. Westerterp KR (2009) Assessment of physical activity: a critical appraisal. Eur J Appl Physiol 105, 823-828.

40. Hill TR, O'Brien MM, Cashman KD et al. (2004) Vitamin D intakes in 18-64-y old Irish adults. Eur J Clin Nutr 58, 1509-1517.

41. O'Brien MM, Kiely M, Harrington KE et al. (2001) The North/South Food Consumption Survey: vitamin intakes in 18-64-year old-adults. Public Health Nutr 4, 1069-1079.

42. Kiely M, Hannon EM, Walton J et al. (2005) Vitamin D intakes in Irish 5-12 year old schoolchildren. Proc Nutr Soc 64, 38A.

43. Holick MF (2008) Vitamin D - a D-lightful health perspective. Nutr Rev 66, Suppl. 2, S182-S194.

44. Ovesen L, Andersen R \& Jakobsen J (2003) Geographical differences in vitamin D status with particular reference to European countries. Proc Nutr Soc 62, 813-821.

45. McCarthy D, Collins A, O'Brien M et al. (2006) Vitamin D intake and status in Irish elderly women and adolescent girls. Irish J Med Sci 175, 14-20.

46. Hill TR, Flynn A, Kiely M et al. (2006) Prevalence of suboptimal vitamin D status in young, adult and elderly Irish subjects. Irish Med J 99, 48-49.

47. Vieth R (2004) Why the optimal requirement for vitamin $\mathrm{D}_{3}$ is probably much higher than what is officially recommended for adults. J Steroid Biochem Mol Biol 89-90, 575-579.

48. Cashman KD, Hill TR, Lucey AJ et al. (2008) Estimation of the dietary requirement for vitamin $\mathrm{D}$ in healthy adults. $\mathrm{Am}$ J Clin Nutr 88, 1534-1542.

49. Cashman KD, Wallace JMW, Horigan G et al. (2009) Estimation of the dietary requirement for vitamin $\mathrm{D}$ in free-living adults $\geq 64$ y of age. Am J Clin Nutr 89, $1366-1374$
50. Institute of Medicine (2011) Dietary Reference Intakes Calcium and Vitamin D. Washington, DC: National Academies Press; available at http://www.nap.edu/open book.php?record_id $=13050$ \&page $=9$

51. Ng MK (2007) New perspectives on Mars and Venus: unraveling the role of androgens in gender differences in cardiovascular biology and disease. Heart Lung Circ 16, 185-192.

52. National Health and Medical Research Council (2003) Food for Health. Dietary Guidelines for Australians. A Guide to Healthy Eating. Canberra: Australian Government Department of Health and Aging; available at http:// www.health.gov.au/internet/main/publishing.nsf/Content/ health-pubhlth-strateg-food-guide-index.htm

53. Galvin MA, Kiely M, Harrington KE et al. (2001) The North/ South Ireland Food Consumption Survey: the dietary fibre intake of Irish adults. Public Health Nutr 4, 1061-1068.

54. World Health Organization \& Food and Agricultural Organization of the United Nations (1998) Carbohydrates in Human Nutrition: Report of a Joint FAO/WHO Expert Consultation. FAO Food and Nutrition Paper no. 66. Rome: FAO; available at http://www.fao.org/docrep/w8079e/ w8079e00.htm

55. Konig KG (2000) Diet and oral health (consensus statement on diet). Int Dent J 50, 162-174.

56. Flynn MAT, Sugrue DD, Codd MB et al. (1996) Women's dietary fat and sugar intakes: implications for food-based dietary guidelines. Eur J Clin Nutr 51, 713-719.

57. Drummond S \& Kirk T (1999) Assessment of advice to reduce dietary fat and non-milk extrinsic sugar in a freeliving male population. Public Health Nutr 2, 187-197.

58. Hill JO \& Prentice AM (1995) Sugar and body weight regulation. Am J Clin Nutr 62, 1 Suppl., 264S-274S.

59. MacDiarmuid JL, Vail A, Cade JE et al. (1998) The sugar-fat relationship revisited: differences in consumption between men and women of varying BMI. Int J Obes Relat Metab Disord 22, 1053-1061.

60. US Department of Agriculture (2010) Report of the Dietary Guidelines Advisory Committee on the Dietary Guidelines for Americans. Washington, DC: USDA; available at http:// www.cnpp.usda.gov/DGAs2010-DGACReport.htm

61. Food Safety Authority of Ireland (2008) Trans Fatty Acid Survey (2007) - Retail Products. Dublin: FSAI; available at http://www.fsai.ie/uploadedFiles/Monitoring_ and_Enforcement/Monitoring/Surveillance/trans_fatty_survey_ retail07.pdf

62. Food Safety Authority of Ireland (2008) Trans Fatty Acid Survey of Fast Foods. Dublin: FSAI; available at http:// www.fsai.ie/search-results.html?searchString $=$ Trans $\% 20$ Fatty $\%$ 20Acid\%20Survey

63. Cantwell MM, Flynn MAT, Cronin D et al. (2005) Contribution of foods to trans unsaturated fatty acid intake in a group of Irish adults. J Hum Nutr Diet 18, 377-385.

64. Department of Health and Children, Health Service Executive (2009) National Guidelines on Physical Activity in Ireland. Dublin: Department of Health and Children; available at http://www.getirelandactive.ie/pdfs/GIA_GUIDE.pdf

65. Hill JO (2009) Can a small change approach help address the obesity epidemic? Am J Clin Nutr 89, 477-484.

66. Flynn MAT, McNeil DA, Maloff B et al. (2006) Reducing obesity and related disease risk in children and youth: a synthesis of evidence with 'best practice' recommendations. Obes Rev 7, Suppl. 1, 7-66. 